\title{
O032. Associations between any headache and obesity: results from a systematic review and meta-analysis of observational studies
}

\author{
Diana Degan", Raffaele Ornello, Cindy Tiseo, Amleto Gabriele, Francesca Pistoia, Antonio Carolei, Simona Sacco \\ From Abstracts from the 1st Joint ANIRCEF-SISC Congress \\ Rome, Italy. 29-31 October 2015
}

\section{Background}

Data about the association between migraine and obesity are controversial, but a recent meta-analysis showed an association between the two conditions [1]. As numerous studies addressing the possible association between any headache (including migraine) and obesity have provided conflicting findings $[2,3]$, we therefore performed a systematic review and meta-analysis of observational studies, to assess the associations between any headache and obesity and pre-obesity.

\section{Materials and methods}

Data were obtained through multiple electronic databases up to April 2015, using the terms "migraine" OR "headache" in combination with "obesity" OR "pre-obesity" OR "body mass index". Out of 2,022 records, we finally included 4 studies [4-7]. We obtained pooled adjusted effect estimates (PAEE) of the risk of having any headache in obese and pre-obese subjects versus normal weight subjects, and in obese and pre-obese women versus normalweight women. To obtain PAEE the natural logarithm of each single estimate was weighed by the inverse of its variance. Only studies written in the English language reporting a clearly, unequivocal definition of exposure and outcome variables were included. To reduce methodological heterogeneity we performed our analyses including only the studies which defined BMI categories according to the World Health Organization (WHO) criteria for Western populations (underweight, $<18.50 \mathrm{~kg} / \mathrm{m} 2$; normal range, 18.50 - $24.99 \mathrm{~kg} / \mathrm{m} 2$; overweight, $\geq 25.00 \mathrm{~kg} / \mathrm{m} 2$; pre-obesity, 25.00 - $29.99 \mathrm{~kg} / \mathrm{m} 2$; obesity, $\geq 30.00 \mathrm{~kg} / \mathrm{m} 2$ ).

\section{Results}

We found an increased risk of any headache in obese versus normal-weight subjects in 3 studies [5-7]; overall PAEE 1.29, (95\% confidence interval [CI] 1.04-1.60; $\mathrm{p}=0.022$ ); in obese versus normal-weight women in 2 studies [4,5]; overall PAEE 1.41, (95\% CI 1.23-1.62; $\mathrm{p}<0.001)$ and in pre-obese versus normal-weight women in 2 studies [4,5]; overall PAEE 1.13, (95\% CI 1.01-1.25; $\mathrm{p}=0.025)$. When considering pre-obese versus normal-weight subjects in 3 studies [5-7], we did not find an increased risk of any headache (overall PAEE 1.06, 95\% CI 0.94-1.18; $\mathrm{p}=0.335$ ).

\section{Conclusions}

The meta-analysis of the available observational studies suggested an association between any headache and obesity, that was stronger in the female gender, and between any headache and pre-obesity in the female gender; these results are in line with the previous metaanalysis findings [1].

\section{Published: 28 September 2015}

\section{References}

1. Ornello R, Ripa P, Pistoia F, Degan D, et al: Migraine and body mass index categories: a systematic review and meta-analysis of observational studies. J Headache Pain 2015, 16:27.

2. Bond DS, Roth J, Nash JM, Wing RR: Migraine and obesity: epidemiology, possible mechanisms and the potential role of weight loss treatment. Obes Rev 2011, 12:e362-e371.

3. Chai NC, Scher Al, Moghekar A, Bond DS, Peterlin BL: Obesity and headache: part I - a systematic review of the epidemiology of obesity and headache. Headache 2014, 54:219-234.

4. Brown WJ, Mishra G, Kenardy J, Dobson A: Relationships between body mass index and well-being in young Australian women. Int J Obes Relat Metab Disord 2000, 24:1360-1368.

\footnotetext{
* Correspondence: degandiana@gmail.com

Department of Neurology, University of L'Aquila, L'Aquila, Italy
} creativecommons.org/licenses/by/4.0), which permits unrestricted use, distribution, and reproduction in any medium, provided the original work is properly cited. The Creative Commons Public Domain Dedication waiver (http://creativecommons.org/publicdomain/ zero/1.0/) applies to the data made available in this article, unless otherwise stated. 
5. Ford ES, Li C, Pearson WS, Zhao G, Strine TW, Mokdad AH: Body mass index and headaches: findings from a national sample of US adults. Cephalalgia 2008, 28:1270-1276.

6. Molarius A, Tegelberg A, Ohrvik J: Socio-economic factors, lifestyle, and headache disorders - a population-based study in Sweden. Headache 2008, 48:1426-1437.

7. Wright $L$, Schur E, Noonan C, Ahumada S, Buchwald D, Afari N: Chronic pain, overweight, and obesity: findings from a community-based twin registry. J Pain 2010, 11:628-635.

doi:10.1186/1129-2377-16-S1-A53

Cite this article as: Degan et al:: O032. Associations between any

headache and obesity: results from a systematic review and meta-

analysis of observational studies. The Journal of Headache and Pain 2015

16(Suppl 1):A53.

\section{Submit your manuscript to a SpringerOpen ${ }^{\mathcal{O}}$ journal and benefit from:}

- Convenient online submission

- Rigorous peer review

- Immediate publication on acceptance

- Open access: articles freely available online

- High visibility within the field

- Retaining the copyright to your article

Submit your next manuscript at $\gg$ springeropen.com 